\title{
Climate Challenge and Implications on Crop Storage: Comparative Analysis of Periodic Temperature and Relative Humidity in Ilorin, Nigeria
}

\author{
A.A Abiodun ${ }^{1 *}$, F.O Ilemaiye ${ }^{1}$, O.A Atibioke ${ }^{1}$, I. Ambee ${ }^{1}$, B.A Ogundele ${ }^{1}$, E.O Ojuekaiye ${ }^{2}$ \\ ${ }^{1}$ Research Outreach Department, Nigerian Stored Products Research Institute, Ilorin, Nigeria. \\ ${ }^{2}$ Research Outreach Department, Nigerian Stored Products Research Institute, Kano Zonal Office, Nigeria
}

*Corresponding Author: A.A Abiodun, Research Outreach Department, Nigerian Stored Products Research Institute, Ilorin, Nigeria.

\begin{abstract}
The global climate challenge is a threat to crop storage especially in areas of temperature and relative humidity. The fundamental objective of this study is to compare temperature and relative humidity for year 2012, 2013 and 2014. A critical note was taken of the annual average against the recommended $27^{\circ} \mathrm{C}$ and $70 \%$ relative humidity. Weather parameters were down loaded from Campbell Scientific mini weather station for the period under review. Descriptive statistic was used and hypothesis was tested with ANOVA. While mean annual temperature showed not much deviation from the $27^{\circ} \mathrm{C}$, the relative humidity were higher from the recommended $70 \%$ by $6.35 \%, 6.47 \%$, and $9.92 \%$ for years 2012, 2013 and 2014 respectively. At $5 \%$ level of significance, ANOVA revealed that there is no significant difference among temperature $(F=0.34)$ and relative humidity $(F=0.29)$ regimes of the years under study. The use of climate smart technologies research into same and government policies on climate change were recommended.
\end{abstract}

Keywords: Climate, Temperature, Relative humidity, Moisture content

\section{INTRODUCTION}

The city of Ilorin (GPS Coordinate N08'27.286' E004'33.248') lies within the semi-savannah agricultural zone is hot sub-humid and humid tropical.The mean annual rainfall of the zone ranges from $800-2000 \mathrm{~mm}$ with annual average of 187-220 rainy days. Crop storage in this zone like any other tropical zone depends to a large degree on prevailing temperature and relative humidity. Agboola (1982) posited that the moisture content of crops especially grains, pulses, oil seeds e.t.c which depends on prevailing relative humidity is required to be reduced to a minimum level known as "safe level" before such crops can be successfully stored. Temperature is also an important physical factor in crop storage. Most insects and micro-organisms have optimum temperatures at which they can grow, develop and reproduce or multiply abundantly. Temperature fluctuation causes condensation and moisture migration in Silos leading to extensive mould development and caking of grains stored resulting in heavy losses. He stated determined moisture content equilibrium for produce at $27^{\circ} \mathrm{c}$ temperature and $70 \%$ relative humidity.

The challenge posed by climate in terms of global warming is of serious concern in the area of crop storage. Mendelsohn (2009) pointed out that warming is expected to cause large damages to agriculture in developing countries over the next century. An Australian study by Zhou et al (2001) on the effect of storage temperature on cooking behaviour of rice discovered that higher temperature storage led to greater water uptake and reduced $\mathrm{pH}$. Hardness increased and adhesiveness reduced following storage at $37^{\circ} \mathrm{C}$ compared to $4^{\circ} \mathrm{c}$. Cooked rice following storage at $4^{\circ} \mathrm{c}$ showed smoother surfaces than that of the cooked rice following storage at $37^{\circ} \mathrm{c}$. This study assertion was confirmed by Park et al (2012) who indicated that storage temperature is an important factor affecting the physicochemical properties of rice and therefore recommended short storage periods below room temperature to maintain rice quality.

Temperature also plays a sensitive role in storage of seeds. Various authors have pointed out the effects of various temperature regimes o storage of seeds (Guadra et al 2002, Sari and Tutar 2009, 
Small and Brooks 2012). In areas of livestock production, storage losses have been recorded due to effects of temperature. Love et al (2002) revealed that sperm DNA from subfertile stallions decline at a greater rate than that from fertile ones between 20-31 hours when stored at $5^{\circ} \mathrm{c}$ while Sahan et al 2003 pointed out that Ostrich eggs stored at $21^{\circ} \mathrm{C}$ or less after collection to maximise hatchability.

Maw et al (2005) stated that low warm air storage proved suitable for mid-term storage of healthy onions and Langley (2010) discussed how psychometrics-the determination of physical and thermodynamic properties of gas vapour mixtures is related to grains fruits and potatoes drying and storage. Seed viability is also affected by relative humidity. According to Villiers et al (2003), an increase in relative humidity generally resulted in a decrease in seed viability. The effects of temperature and relative humidity on crop storage cannot be over emphasised. The current global warming called for a review of climate parameters of food storage.

The fundamental objective of this paper is to compare periodic regimes of temperature and relative humidity and give their implications on food storage. In doing this the following objectives will be addressed

1. Enumerate moisture content equilibrium values of some produce at $27^{\circ} \mathrm{c}$ and $70 \%$ relative humidity

2. Compare monthly temperature and relative humidity values for a 3 year period.

3. Investigate annual deviations of temperature and relative humidity of the study periods from $27^{\circ} \mathrm{C}$ and $70 \%$ relative humidity.

Hypothesis

Due to the effects of global warming, the following hypothesis will be tested at 5\% level of significance.

Ho: There is no significant difference among temperature and relative humidity regimes of the study period.

Methodology

Daily temperature and relative humidity reading for years 2012, 2013 and 2014 were downloaded from Campbell Scientific mini weather Station at the Nigerian Stored Products Research Institute Ilorin, Nigeria. The readings were then converted to monthly and yearly averages. Primary data of moisture content equilibrium $\left(\right.$ at $27^{\circ} \mathrm{c}$ ) values of produce at relative humidity $70 \%$ was obtained from literature (Agboola, 1982)

Graphical analyses of monthly temperature and relative humidity were drawn and table of deviation of annual means was drawn. Descriptive statistics was used for the variables while the hypothesis was tested at $5 \%$ level of significance with ANOVA.

\section{RESULTS AND DISCUSSION}

Most stored products are hygroscopic and are therefore influenced by the temperature and relative humidity of the atmosphere. The moisture content equilibrium at $27^{\circ} \mathrm{C}$ value for some products at relative humidity of $70 \%$ as seen in table 1. (Agboola,1982).

Table1. Moisture Content Equilibrium Value of Some Products at $27^{\circ} \mathrm{C}$ and $70 \%$ Relative Humidity

\begin{tabular}{|l|l|}
\hline Commodity & Moisture Content \% \\
\hline Maize & 13.5 \\
\hline Wheat & 13.5 \\
\hline Sorghum & 16.0 \\
\hline Millet & 16.0 \\
\hline Paddy & 15.0 \\
\hline Rice & 13.0 \\
\hline Cowpea & 15.0 \\
\hline Beans & 15.0 \\
\hline Groundnut (shelled) & 7.0 \\
\hline Cottonseed & 10.0 \\
\hline
\end{tabular}


Climate Challenge and Implications on Crop Storage: Comparative Analysis of Periodic Temperature and Relative Humidity in Ilorin, Nigeria

\begin{tabular}{|l|l|}
\hline Cocoa beans & 7.0 \\
\hline Copra & 7.0 \\
\hline Palm kernels & 5.8 \\
\hline Garri (yellow) & 13.6 \\
\hline Garri (white) & 12.7 \\
\hline Dried Yam & 15.8 \\
\hline
\end{tabular}

Source: Agboola 1982

These are examples of safe moisture level for storage of the crops listed above. If the temperature and relative humidity are not at equilibrium at $27^{\circ} \mathrm{c}$ and $70 \%$ respectively, the implication is that crop storage will be at jeopardy. The figure below shows temperature and relative humidity for years 2012 , 2013 and 2014.

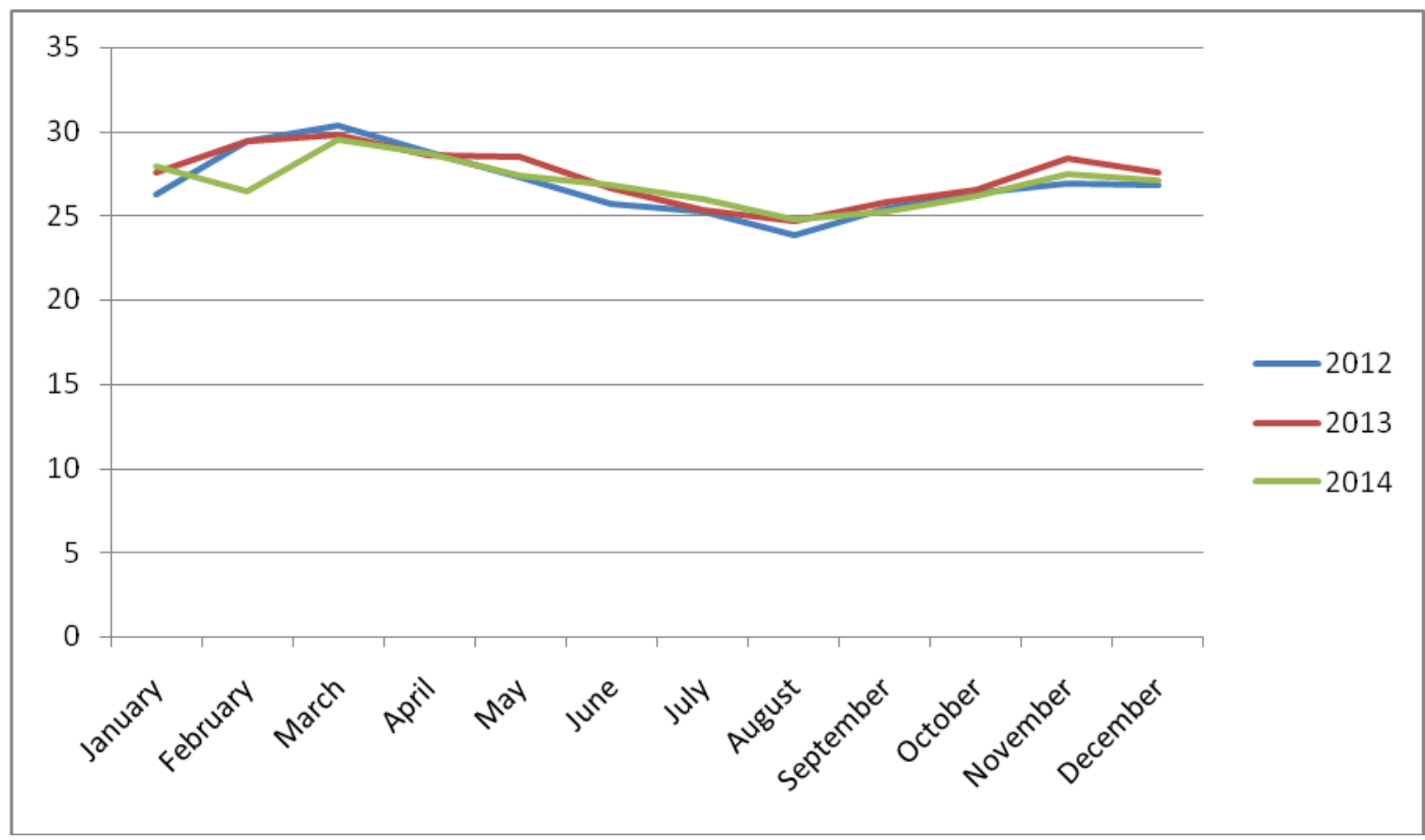

ATMOSPHERIC PARAMETERS: Temperature

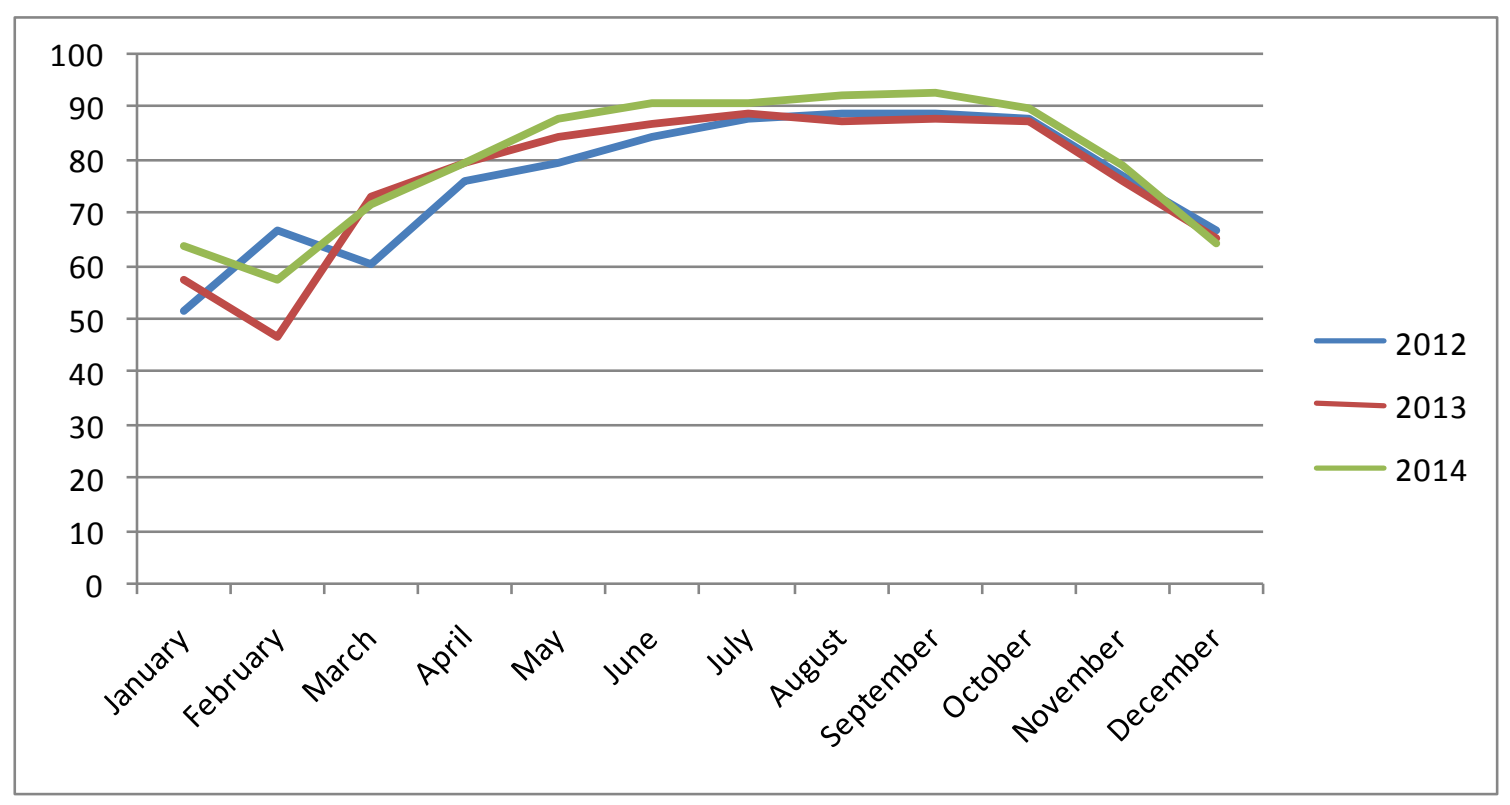

MOSPHERIC PARAMETERS: Relative Humidity

The year 2013 had relatively higher temperature than others. However temperature regimes between October and December are relatively at par with the recommended $27^{\circ} \mathrm{c}$. Months of January to April 
Climate Challenge and Implications on Crop Storage: Comparative Analysis of Periodic Temperature and Relative Humidity in Ilorin, Nigeria

witnessed higher temperature. The implications of higher temperature for food storage is resultant cracking and caking, Caking occurs as a result of heat generated within the storage chamber which causes moisture migration and condensation. High temperature here aided the survival of certain insects in habitats where they do not normally exist, Incidence of locust (Locustmigratoric) that are usually restricted to the semi-arid agro-ecological zones of Nigeria have been reported in forest and savannah zones. Lower temperature than $27^{\circ} \mathrm{c}$ have been reported between June and October. The implication is that produce will have the tendency to absorb water from the atmosphere, a situation that will be conducive for mould growth. The year 2014 witnessed higher relative humidity than other years. Months of December to March had humidity below the recommended 70\%. Other months (April-November) recorded humidity that is more than $70 \%$. Much water vapour in the air will cause produce to be damp and lead to mould growth.

Table2. Annual Temperature Compared to Recommended Standard for Storage

\begin{tabular}{|l|l|l|l|}
\hline Months & 2012 & 2013 & 2014 \\
\hline January & 26.272 & 27.600 & 27.912 \\
\hline February & 29.462 & 29.438 & 26.469 \\
\hline March & 30.381 & 29.792 & 29.488 \\
\hline April & 28.833 & 28.606 & 28.621 \\
\hline May & 27.355 & 28.476 & 27.422 \\
\hline June & 25.763 & 26.603 & 26.852 \\
\hline July & 25.317 & 25.341 & 26.001 \\
\hline August & 23.878 & 24.701 & 24.817 \\
\hline September & 25.503 & 25.829 & 25.315 \\
\hline October & 26.345 & 26.572 & 26.224 \\
\hline November & 26.989 & 28.433 & 27.476 \\
\hline December & 26.821 & 27.605 & 27.062 \\
\hline Annual Average & 26.910 & 27.416 & 26.972 \\
\hline Recommended Temperature & 27.000 & 27.000 & 27.000 \\
\hline Deviation & -0.090 & +0.416 & -0.028 \\
\hline
\end{tabular}

Deviations from the recommended storage temperature are shown from the annual mean temperature of the years under review on the table 2 . A positive deviation of $0.42^{\circ} \mathrm{C}$ occurred in the year 2013. This is a slight deviation whereas years 2012 and 2014 witnessed tolerable negative deviations of $-0.09^{\circ} \mathrm{C}$ and $-0.03^{\circ} \mathrm{c}$. If temperature oscillates within the recommended range of $27^{\circ} \mathrm{c}$. It is pertinent therefore to use climate smart technologies for food storage. Examples of these are evaporative coolers, solar dryers, ventilated barns and sheds.

Table3. Annual Relative Humidity Compared to Recommended Standard

\begin{tabular}{|l|l|l|l|}
\hline Months & 2012 & 2013 & 2014 \\
\hline January & 51.399 & 57.086 & 63.784 \\
\hline February & 66.789 & 46.487 & 57.217 \\
\hline March & 60.098 & 72.795 & 71.482 \\
\hline April & 75.925 & 79.281 & 79.616 \\
\hline May & 79.501 & 84.412 & 87.937 \\
\hline June & 84.511 & 86.563 & 90.491 \\
\hline July & 88.041 & 88.623 & 90.487 \\
\hline August & 88.779 & 87.184 & 92.231 \\
\hline September & 89.007 & 87.472 & 92.662 \\
\hline October & 88.217 & 86.956 & 89.940 \\
\hline November & 77.054 & 75.706 & 78.835 \\
\hline December & 66.914 & 65.054 & 64.322 \\
\hline Annual Average & 76.353 & 76.468 & 79.917 \\
\hline Recommended Humidity & 70.000 & 70.000 & 70.000 \\
\hline Variance & +6.353 & +6.468 & +9.917 \\
\hline
\end{tabular}

On the contrary, deviations from relative humidity are very high for the three year period as shown on table 3. Positive deviation of $6.35 \%, 6.47 \%$ and $9.92 \%$ for years 2012, 2013 and 2014 implies that the 
amount of water vapour in the atmosphere is too high for effective storage of crops. There is an increasing trend from one year to the previous year during the study. Dampness of stored commodities will encourage the growth of micro-organisms which will lead to discolouration of produce, unpleasant flavour and odour of crops, biochemical changes, rotting and caking. It is pertinent therefore to fund effective research into climate smart technologies that will address the issue of high relative humidity within the ambient air so as to have effective food storage.

Hypothesis Testing

The hypothesis is not significant difference among temperature and relative humidity regimes of the study period was tested at $5 \%$ level of significance. The results are shown in table 4 and 5 .

Table4. Test of Significance among Temperature Regimes

\begin{tabular}{|l|l|l|l|l|l|}
\hline Sources of Variation & df & SS & MS & F-Ratio & Decision \\
\hline BSS & 2 & 1.67 & 0.835 & 0.34 & NS \\
\hline WSS & 35 & 4.90 & 2.45 & & \\
\hline
\end{tabular}

The table revealed that there is no significant difference among the temperature regimes of 2012 , 2013 and 2014. $(\mathrm{F}=0.34)$. The climate change phenomenon may take more than hundred years to be physically noticed.Table 5: Test of Significance among Relative Humidity Regimes

\begin{tabular}{|l|l|l|l|l|l|}
\hline Sources of Variation & df & SS & MS & F-Ratio & Decision \\
\hline BSS & 2 & 98.3 & 49.15 & 0.29 & NS \\
\hline WSS & 35 & 5603.46 & 169.80 & & \\
\hline
\end{tabular}

The table revealed that there is no significant difference among the relative humidity regimes of the study period. The increasing trend in annual relative humidity average will be noticed over a long period of years.

\section{CONCLUSION AND RECOMMANDATIONS}

Where annual temperature regime oscillates between the recommended $27^{\circ} \mathrm{c}$ for food storage with negligible deviations, the deviations of relative humidity regimes from the recommended $70 \%$ is manifest. There is therefore the threat of climate challenge to food storage while the use of climate smart technologies and adequate research into same are recommended, government should critical take climate change issues as a serious element of policy formulations to be able to safe food for future food security.

\section{REFERENCES}

Adedipe N.O,Bakshi J.S, Odegbaro O.A, Aliyu A: (1996) Evolving the Nigerian Agricultural Research Strategy Plan. A gro-ecological input

Agboola S.D: (1982): Research for Effective Food Storage in Nigeria. NSPRI Occasional Paper Series No 4 1982

Cuadra -I-C-de-la, Mansur-V-L, Verdugo-R-G, Arriagada-G-L (2002): Deterioration of Leucocoryncspp seeds as a function of storage time.Agricultura Tecnica, 2002

Garcia . M, Raes. D, Jacobson S.E, Michel T. (2007): Agro-climatic constraints for rain-fed Agriculture

In the Bolivian Altiplaon. Journal of Arid Environments

Kaiser H.M and Crosson P. (1995): Implications of Climate Change for U.S Agriculture. American Journal of Agricultural Economics

Langley, R (2010): Dewpoint. Landwards 2010

Love C.C., Thompson J.A., Lowry V.K, Varner D.D (2002): Effect of Storage time and Temperature on Stallion Sperm DNA and Fertility: Theriogenology 57 (2002).

Maw B.W, Seebold K.W, Purvis A.C, Paulk J.T (2005): Low humidity, warm air storage effective for mediumterm storage of sweet onions. Applied Engineering in Agriculture,2005.

Mendelshon R. (2009): The Impact of Climate Change on Agriculture in Developing Countries. Journal of Natural Resources Policy Research.Vol 1 No 1.

Molua E.L. (2008): Turning up the heat on African Agriculture:the impact of climate change on Cameroon's agriculture. African Journal of Agriculture and research economic, 2008,2(1) 
Climate Challenge and Implications on Crop Storage: Comparative Analysis of Periodic Temperature and Relative Humidity in Ilorin, Nigeria

Nastis S.A Michailidis .A, Chatzitheodoridis F (2012): Climate Change and Agricultural productivity. African Journal of Agricultural Research

Ozor N and Nnaji C.(2011): The Role of Extension in Agricultural Adaptation to Climate Changein Enugu State, Nigeria. Journal of Agricultural Extension and Rural Development

Park C.E, Kim V.S., Park J.K, Kim B.K 92012) Changes in Physio-chemical Characteristics of Rice During Storage at different Temperature. Journal of Stored Products Research

Sahan U, Ipek A, Yilmaz B (2003): The Effects of Storage temperature and position in embryonic mortality of Ostrich (Strthiocamelus) eggs. South African Journal of Animal Science 2003

Sari A.O, Tutar M (2009): Effect of light, cold storage and temperature on seed germination of golden thistle (Scolymushispanium L). Journal of herbs, spices and medicinal plants

Small E. And Brookes (2012): Temperature and moisture content of storage maintenance of germination. Journal of Natural Fibres

Villiiers A.J.de, Rooyen M.W-van, Theron G.K (2003): Germination Strategies of Strandveld Succulent Karoo POlantspicies for revegetation purposes: Effect of relative humidity and storage on seed viability. South African Journal of Plant and Soil

Zhou .Z, Robards K, Helliwells and Blanchard C (2007): Effect of Storage Temperature on Cooking behaviour of rice. Food Chemistry.

Citation: A.A Abiodun et al., "Climate Challenge and Implications on Crop Storage : Comparative Analysis of Periodic Temparature and Relative Humidity in Ilorin, Nigeria", International Journal of Research Studies in Agricultural Sciences (IJRSAS), vol. 3, no. 9, p. 6, 2017. http://dx.doi.org/10.20431/24546224.0309001

Copyright: (C) 2017 Authors. This is an open-access article distributed under the terms of the Creative Commons Attribution License, which permits unrestricted use, distribution, and reproduction in any medium, provided the original author and source are credited. 